\title{
Constituency Influence in Parliament
}

\author{
StUART SOROKA McGill University \\ ERIN PENNER University of British Columbia \\ KELLY BLIDOOK Memorial University of Newfoundland
}

This paper examines relationships between constituency characteristics and individual legislators' behaviour in a parliamentary system. This kind of "dyadic" representation has received considerable attention in the US, particularly with the study of roll call voting. Outside the US, however, the study of individual representatives' behaviour has been more difficult. In many cases, information on individuals' behaviour has been difficult to attain; moreover, in many countries there are relatively few observable policy venues in which individual legislators have an opportunity for anything other than toeing the party line.

Acknowledgments: Previous versions of this paper were presented at the 2006 annual meeting of the American Political Science Association, Philadelphia PA, and at the 2006 annual meeting of the Canadian Political Science Association, Toronto ON. This research was funded by a Social Sciences and Humanities Research Council of Canada Standard Research Grant. We are very grateful to Denise Ledoux, Peter Niemczak, and others at the Library of Parliament, who provided much of the necessary data on MPs and electoral outcomes as well as valuable commentary at an early presentation of these data. We are also indebted to Lori Young, Iris Simixhiu, MarieJosée Bouffard, Michelle Meyer, and Zach Finkelstein, the principal coders on the project; to Keith Banting, Jenny Hunt, Jim Kelly, Jack Sandberg, and Arthur Sweetman for comments on previous versions; and to the Hons. Warren Allmand, Bill Blaikie, Ed Broadbent, Joe Clark, Peter Milliken, and Senator Gerald Comeau, each of whom was kind enough to share with us some of their knowledge of Parliament and Question Period.

Stuart Soroka, Department of Political Science, McGill University, 855 Sherbrooke St West, Montréal, Québec, Canada H3A 2T7, stuart.soroka@mcgill.ca.

Erin Penner, Department of Political Science, University of British Columbia, 2642 Oxford St. (BSMT), Vancouver, British Columbia, Canada V5K IN3, erin.penner@, mcgill.ca.

Kelly Blidook, Department of Political Science, Memorial University of Newfoundland, Science Building, SN-2042, St. John's, Newfoundland, Canada A1B 3X9, kblidook@mun.ca. 
Dyadic representation is nevertheless of some importance outside the US, theoretically if not practically speaking. That is, even where it is weak or difficult to measure, the strength or fragility of dyadic representation is a defining feature of any political system. Consider recent discussions of electoral change in New Zealand, British Columbia, and Ontario (all with parliamentary systems), each of which had the strength of the connection between representatives and geographic constituencies as a central theme. And some parliamentary systems may in fact exhibit a considerably stronger dyadic connection than past work has suggested. Consider Anglo-American countries combining the strong party discipline of a parliamentary system, likely dampening dyadic representation, with a single member plurality (SMP) electoral system, identified in the US context as the critical driver of the dyadic link. As in the US, citizens in these systems vote for individual representatives, creating conditions for a strong dyadic connection. Moreover, these citizens often vote with the expectation that their elected member will at least in part represent their geographic constituency. Do these other SMP systems, in spite of parliamentary institutions, exhibit dyadic representation? Put differently, does the party focus of a parliamentary system quash entirely the candidate-oriented incentives of SMP elections?

This question is relevant not just to Canada, but to the larger comparative literature on the relationship between political institutions and the nature and strength of democratic representation. The literature on this topic is nonetheless rather sparse. To be sure, there is a growing body of comparative work on roll call voting, but much of this work focuses on party cohesion, or the relatively rare breakdown of cohesion (for example, Wilson and Wiste, 1976; Wood and Pitzer, 1982; Mughan and Scully, 1997; Kam, 2001; Hix, 2002). Dyadic representation is thus portrayed as quite limited. Roll call votes are not the only venue in which dyadic representation can occur, however. This paper accordingly examines dyadic representation outside both the US and the roll call voting contexts.

The analysis focuses on a model of oral questions in the Canadian House of Commons, drawing on an exhaustive dataset of over 43,000 oral questions (from 1983 to 2004), combined with data on constituencylevel demographics and electoral outcomes. Questions, as an example of individual legislative behaviour, are in our model driven by a combination of procedural, institutional and party factors, constituency interests, and electoral instability. Results provide evidence of dyadic representation across several policy domains, an important finding given the partyfocused tone of the existing literature on parliamentary systems. The effects of electoral instability - as a mediator of constituency interestsprovide complementary evidence that competition increases dyadic representation by members of Parliament (MPs), in line with some of the classic US literature and at odds with much of the existing literature on 
Abstract. "Dyadic representation" has received considerable attention in the US, but much less attention in parliamentary systems where party discipline strongly limits representatives' capacity for individual action. A link between the legislative behaviour of representatives and the preferences of their geographic constituencies may nevertheless exist outside the US, however, particularly in single member plurality systems where the "electoral connection" is strong. This paper tests for evidence of this dyadic relationship in Question Period in the Canadian Parliament, across three policy domains: defense, debt and taxes, and welfare. As anticipated, there is evidence of dyadic representation in Canada. Results are discussed as they pertain to the comparative study of legislative institutions and political representation.

Résumé. La «représentation dyadique» a reçu une attention considérable aux États-Unis, mais elle est beaucoup moins étudiée au sein des démocraties parlementaires où la discipline de parti limite fortement la marge de manœuvre des élus. Malgré tout, le lien entre le comportement politique des élus et les préférences de leurs commettants demeure important ailleurs qu'aux États-Unis, mais particulièrement dans les systèmes électoraux pluralitaires où la «connexion électorale» est forte. Cet article s'intéresse à cette représentation dyadique dans le cadre de la période des questions au Parlement canadien et plus particulièrement pour les trois enjeux suivants : la défense nationale, la politique fiscale et les services sociaux. Tel qu'attendu, la représentation dyadique semble se confirmer au Canada. Les résultats des analyses statistiques sont discutés et apportent un éclairage original sur l'étude comparée des institutions législatives et de la représentation politique.

parliamentary systems. Before setting out our model, however, the following section reviews the relevant literatures on dyadic representation and Question Period.

\section{Dyadic Representation?}

The representation of public preferences is one of the critical features of representative democracy. Dahl's line, "I assume that a key characteristic of a democracy is the continuing responsiveness of the government to the preferences of its citizens, considered as political equals" (1971: 1-2) is often cited for good reason; it nicely identifies the centrality of the opinion-policy link in democratic theory. ${ }^{1}$

Pitkin's work on political representation is also influential here. Her "substantive" representation, in which representatives act "in the interest of the represented, in a manner responsive to them" (1967:209) has become a defining feature of empirical work on representative democracy.

The means by which substantive representation comes to exist is another matter. One critical question focuses on whether political representation should occur at the level of individual representatives or the system as a whole. There is a strong argument for the latter, that representation, particularly substantive policy representation, is necessarily at the system level. Policy is not the outcome of a single legislator, after all, but an entire policy-making system (see, for example, Hurley, 1982). ${ }^{2}$

Even so, the relationship between an individual representative and her or his geographic constituency is a lynchpin of single-member plu- 
rality (SMP) political systems. Constituencies elect individuals, and there is typically a reasonable and widespread expectation that these individuals will represent the interests of their constituents. This kind of "dyadic" (Weissberg, 1978) representation has motivated a vast body of work on roll call voting in the US. The early literature-including Miller and Stokes's "Constituency Influence in Congress" (1963), Mayhew's Congress: The Electoral Connection (1974), Clausen's How Congressmen Decide (1973), and Kingdon's Congressmen's Voting Decisions (1973) remains critical. And there is a considerable body of work confirming and extending these authors' evidence that the voting behaviour of representatives is, albeit to varying degrees, driven by constituency interests. ${ }^{3}$

This notion of dyadic representation has nonetheless been given relatively short shrift in parliamentary systems. In these systems, where the legislature and executive are fused, the need for a government to hold the confidence of the legislature can result in relatively strong party cohesiveness, or party discipline (Diermeier and Feddersen, 1998; Huber, 1996). The potential for representatives to act independently is accordingly relatively limited. This is particularly true for Canada, where leaders have considerable power to reward or punish MPs through their control over the MPs' career advancement opportunities and candidacy in future elections (Docherty, 1997; Savoie, 1999; Carty et al., 2000). This further enhances the executive's supremacy over the legislature (Atkinson and Thomas, 1993). ${ }^{4}$

Given that the Canadian system allows party leaders to dictate the behaviour of MPs, and the executive to dictate what will be legislated by the House, the Canadian literature has been heavily focused on institutional structure as the key factor that explains governance (Mallory, 1971; Stewart, 1977; Franks, 1987). The system is regarded as being heavily centralized, leaving little space for any meaningful policy role by MPs (Savoie, 1999); to the extent that MPs have an independent role, it may be most evident in closed-door caucus meetings where party policies are established. In most cases in which MPs receive specific attention for their potential roles as individuals, the story is generally one of institutional constraints (Franks, 1987; Docherty, 1997).

That MPs are rarely viewed as having represented their constituency is readily evident in polling results (for example, Anderson and GoodyearGrant, 2005). Clarke and Kornberg, (1992) attribute opinion to the institutional constraints described here, as well as the comparatively short parliamentary careers of Canadian MPs during which it is difficult to build a reputation for responsiveness. There are nevertheless hints in work by Kornberg and colleagues that MPs have an interest in something other than toeing the party line. Their interviews suggest that many Canadian MPs are genuinely interested in affecting policy — motivated by both their 
own interests and those of their constituency (see Kornberg 1966, 1967; Kornberg and Mishler, 1976; also Atkinson, 1978).

Kornberg's findings are echoed in more recent work, which suggests both that many MPs give a high priority to constituency concerns (for example, Docherty, 1997), and that this behaviour can pay off in the form of a "personal vote" (Cain et al., 1987; Blais et al., 2003). ${ }^{5}$ Similarly, Norton (1994) suggests that UK MPs have increasingly felt a pressure to act on behalf of their constituency. Historically speaking, UK MPs rarely participated in Question Time; now many propose the allowable maximum number of questions. ${ }^{6}$

To be clear, it is still the case that most work on parliamentary systems emphasizes the strength of parties. MP interviews suggest the possibility of dyadic representation, but empirical evidence of this representation - particularly in the Canadian context-is virtually nonexistent. We accordingly know very little about the nature and scope of dyadic representation in parliamentary systems. The current research is aimed at filling at least part of this gap. We are on the one hand agnostic but interested; even if dyadic representation is very low, we would like to find empirical evidence that this is the case. But, on the other hand, we also believe there are good reasons to expect a certain degree of individual behaviour from MPs.

First, Canada's SMP system provides a strong electoral incentive for constituency representation. The possibility of individual electoral victory, despite party electoral defeat, as well as considerable local control over the nomination process, creates conditions in which it may be beneficial for a candidate to cultivate an image or message shaped by localand not party-concerns (Carey and Shugart, 1995; see also Strom, 1997; Cain et al., 1987). Indeed, recent work on constituency service finds that representatives in single-member systems (including Canadian MPs) are more likely to say they have a constituency focus than are representatives in multi-member systems (Heitshusen et al., 2005). ${ }^{7}$ In short, just as in the US, the Canadian SMP system creates a strong incentive for representatives to demonstrate active, constituency-focused behaviour in Parliament. Second, the Canadian legislative process provides a number of venues, outside the largely party-driven legislative votes, in which dyadic constituency representation may be manifest. ${ }^{8}$ Oral Question Period is one such venue.

\section{Question Period?}

Question Period is the most visible part of the Canadian Parliamentary process. Indeed, for most Canadians, Question Period is Parliament. It provides a summary indication of those issues most salient to Canadian 
elected officials; it is a venue for position taking on the part of Government and Opposition members alike; and last, but certainly not least, it plays a starring role in nightly newscasts. ${ }^{9}$

Even so, many will ask whether Question Period really matters. It is not policy making; it is far more symbol than it is substance; and even this most visible part of the parliamentary process is, generally speaking, not very visible to the average Canadian citizen. Let us begin by noting, then, that for Question Period to be valuable for this particular study, we do not require that it have a consistent effect on policy outcomes. The idea of substantive representation assigns considerable importance to the political process, and not just to political outcomes (Pitkin, 1967). Relatedly, Mayhew argues that "politicians often get rewarded for taking positions rather than achieving effects" (2001:251; see also 1974). To the extent that MPs pursue personal votes in the Canadian context, the same dynamic may well be true. Indeed, "position taking" in Canadian parliament may matter a great deal. An MP's actions need not directly affect policy in order for there to be incentives to represent constituency interests in oral questions.

That said, there are isolated instances of Question Period having a direct effect on political and/or legislative outcomes. ${ }^{10}$ Existing research also demonstrates a long-term causal relationship between Question Period and media content on some issues (Soroka, 2002a, 2002b) and argues for the significance of oral questions in politics and policy making more generally (for example, Crimmins and Nesbitt-Larking, 1996; Howlett, 1998). Institutional scholars also suggest that there may be an indirect effect of Question Period on political outcomes. Question Period provides a venue in which Opposition parties can hold the Government to account, criticize Government policies and suggest alternatives, gain experience, and demonstrate their potential as alternatives to the current government (for example, Franks, 1987; Docherty, 1997; outside Canada, see also Chester and Bowring, 1962; Franklin and Norton, 1993). The effect of QP may thus be largely anticipatory-Governments will anticipate pressure and competition in QP and legislate accordingly.

Even so, the direct influence of oral questions on legislative outcomes does not really matter for our purposes. Rather, what matters is that Question Period (1) is seen by MPs as an opportunity to publicly take a position on a given issue, and (2) provides an opportunity for MPs to actually do so. Regarding the former, that it is possible to signal an issue interest through oral questions requires little justification; whether questions are sufficiently public is perhaps another matter. Questions are recorded in Hansard, of course, and broadcast on CPAC, Canada's parliamentary news channel. Both are clearly "public," though of course neither has a large audience. Oral questions are used regularly in media reports, however. Where newspapers are concerned, identifying the prom- 
inence of Question Period is rather simple: over the twenty-year period of this study (1984-2004), the Globe and Mail published 2,025 articles that name Question Period directly. ${ }^{11}$ This translates to almost two direct mentions per week, and likely underestimates the role Question Period plays in media coverage of the House since it captures only those articles that name Question Period directly. That is, it completely ignores the (likely) possibility that an oral question affects the topic of a news story, which then does not cite the question directly.

In addition, MPs themselves regularly advertise their oral questions in their constituency literature and, more recently, on their websites. The latter are of course readily accessible. As of July 2008, 70 per cent of Opposition MPs have their own regularly updated websites; of those, 70 per cent directly mention (and in most cases list verbatim) oral questions that the MP has asked in the House. ${ }^{12}$ Overall, Question Period seems sufficiently public to make it a worthwhile venue for "position taking."

But are MPs provided an opportunity to actually do so? Let us note first that the Canadian Question Period is a relatively unique institution. It is one of the very few that allows MPs to ask questions of ministers without any advance warning. ${ }^{13}$ That said, MPs can by no means ask questions on whatever they want, whenever they wish. Question Period lasts for 40 minutes each day, and questions are allocated mainly to Opposition parties based on their size in the House, with a few remaining questions for Government MPs. Parties plan their questions - both topics and speakers - at morning meetings. The exact process by which questions are selected varies across both parties and leaders. In some cases, questions (and speakers) are selected by the full caucus, with input from many party members; in others, questions are selected by a few elite party members, based on a combination of party interests and backbenchers' priorities or concerns. In either case, in order to ask a particular question, an MP has to get it approved by some of their fellow party members. Nonetheless, if not in a single day then over time, parties will typically have enough questions to both accommodate the party's concerns as well as those of some individual MPs. And even with these limitations, Question Period presents more opportunity for individual behaviour by MPs than do the more tightly controlled legislative votes. Interviews with MPs suggest exactly this: MPs will try to find space for constituency representation in their oral questions. ${ }^{14}$

There is reason to believe that Question Period will capture, if it exists, a certain degree of dyadic representation-symbolic representation (position taking) if not substantive representation (directly impacting policy). That said, there is one additional limitation to Question Period as a venue for study in the present case: it is limited in its ability to reflect the constituency concerns of Government members, since most questions are allocated to Opposition parties (discussed in more detail 
below). This does not preclude dyadic representation, of course, but it does mean that the representation we find here is only part of the story: dyadic representation by governing Cabinet members will not be captured very well in Question Period. Even so, Question Period is an important, and quite visible, policy venue, one that can affect policy debate if not policy itself, and one that can be of considerable importance to an MP looking to publicize a particular issue. We should not underestimate the importance of symbols in legislative politics (for example, Edelman, 1964, 1985). Nor should we underestimate the importance of "position taking" by representatives seeking re-election.

\section{Modeling Dyadic Representation in Question Period}

The focus here is whether and to what extent MPs' oral questions are motivated by constituency interests. Ideally, MPs' behaviour could be linked to constituency policy preferences derived from public opinion polls. These data are not available at the constituency level, however, so this work uses surrogates. When looking at attention to defense issues, we use a very simple measure: the existence of a military base in the MP's constituency. When looking at debt/taxes and social welfare, we use a proxy for constituency preferences based on recent electoral results. Both methods have been used in past US work (for example, Pool et al., 1965; Weber et al., 1972; Weber and Shaffer, 1972; Nice, 1983; Erikson and Wright, 1980); both suffer reliability and validity problems (see especially Erikson et al., 1993). These problems are partly minimized here by focusing on relatively simple issue domains. These issues' emphasis in Canadian Parliament is, we believe, rather clearly connected with (a) the interests of those employed by (or close to those employed by) the military, or (b) generally conservative or liberal policy preferences, as captured using electoral data.

This argument is developed further below, alongside a statistical model appropriate for gauging dyadic representative behaviour in the Canadian House of Commons. The model includes these constituencylevel variables, alongside a battery of variables meant to capture the institutional constraints or incentives likely to affect the number of questions an MP asks in Parliament. In short, we expect the number of questionsregardless of topic - to be driven by (1) a combination of Government versus Opposition and backbench versus cabinet status, and (2) party size in the House. In addition, the number of questions on particular topics will be affected by (3) changes in issue salience across Parliaments and parties, (4) constituency interests, and (5) electoral instability. We describe these variables, and our expectations, in more detail below. First, however, we introduce the dependent variables. 
Our dependent variables are drawn from a content analytic database of all oral questions asked in the House of Commons from mid-1983 (the last Trudeau government) to 2004 (the end of the last Chrétien government). The database includes 43,426 oral questions, spanning five Parliaments $\left(32^{\text {nd }}\right.$ to $\left.37^{\text {th }}\right)$. All questions were coded by topic (and subtopic), using codes are drawn from the US Policy Agendas project (see, for example, Baumgartner and Jones, 2003). ${ }^{15}$ The coding scheme is quite elaborate, including 25 major topic codes and over 100 subtopic codes. The analyses below nevertheless rely on four relatively simple dependent variables - the number of questions asked by each MP in each Parliament on:

- all issues combined

- defense, including military intelligence, arms control, defense alliances, and military installations

- the federal debt and deficit, and taxation, including tax policy and reform

- social welfare, including food stamps, poverty and assistance for lowincome families, elderly assistance programs, and social services. ${ }^{16}$

Debt and taxes are of course separate issues, though we combine them here because these were the two central "right" issues for the period. ${ }^{17}$ Debt/taxes thus stands in contrast to social welfare, the quintessential "left" issue. Note that our data capture only issue mentions, not the tone or direction of questions. As we shall see, this means that when connecting questions with our measures of constituency preferences we assume that (a) debt/taxes questions are largely anti-debt/taxes, and (b) welfare questions are largely pro-welfare. These assumptions are in part tested below when we look at the relationship between issue attentiveness and partisanship. Our own qualitative review of the data suggests that a vast majority (roughly 85 per cent) of social welfare questions are clearly leftleaning, though there is more variance in debt/taxes questions (where roughly 75 per cent are clearly right-leaning). To the extent that our simple measure of issue attentiveness does not capture the direction of comments, however, we expect it to dampen rather than enhance our findings: that is, measurement error in this regard is likely to lead to a more conservative estimate of the dyadic relationship. And our loss in detail is hopefully compensated for in volume-namely, the use of a reliable, exhaustive dataset covering twenty years of legislative behaviour.

For our purposes, then, we collapse these data so that the unit of analysis is members of Parliament (MPs). There is one observation for each MP in each Parliament. ${ }^{18}$ Given that we have data from six Parliaments, and there are roughly 300 (give or take 20) MPs in each, our sample size is 1804 . 
The dependent variables are "count" variables, and our regression analysis accordingly relies on a negative binomial regression model (NBRM). This estimation procedure is more suitable than OLS for count outcomes, typically characterized by (a) only positive values, (b) many zeros, and (c) a long right-hand tail. ${ }^{19}$ We do not wish to spend too much time on the details of NBRMs here. ${ }^{20}$ The general model is however as follows:

$$
\mu_{i p} t_{i p}=\left\{\exp \left(\beta_{0}+\beta_{1} x_{i p 1}+\beta_{2} x_{i p 2}+\ldots \beta_{k} x_{i p k}+\varepsilon_{i}\right)\right\} \times t_{i p},
$$

where $\mu_{i p}$ is the expected number of questions asked by an individual MP $i$ for a single day in Parliament $p$; and $\mu_{i p} t_{i p}$ is the expected count over exposure time $t_{i p}$ - the number of days for which an MP $i$ could ask questions in Parliament $p$ (accounting for the fact that MPs will be able to ask more questions in a longer Parliament than in a shorter one) ${ }^{21}$ This count is a function of various independent variables $(\beta x)$, an error term $\varepsilon,{ }^{22}$ as well as "exposure time." ${ }^{23}$ In the NBRM, an exponential function ensures that predicted values will be non-negative; estimation is undertaken by maximum likelihood.

We present our hypotheses and variables in tandem below. In short, we expect oral questions to be affected by two sets of variables: one set of mainly institutional controls affecting the number of questions an MP asks, regardless of topic, and another set of variables linked to particular topics, and capturing constituency representation by MPs. The first set is as follows:

\section{Government Versus Opposition, and Cabinet Versus Backbench Member}

Unlike other parliamentary systems where Government members use questions to solicit information from other Government ministers, Canadian Government members rarely ask questions. Indeed, governing parties are allotted very few oral questions; those that are asked are typically asked by backbenchers rather than ministers. Where the Opposition is concerned, in contrast, backbenchers tend to ask fewer questions. Instead, members of each party's "shadow cabinet" - which became more formalized (for example, listed and publicized) in the $35^{\text {th }}$ Parliamenttend to ask more questions, particularly those related to the ministry for which the member is a critic. The result is that the expected number of questions varies with membership (or not) in Government, and whether or not they have a Government or Opposition portfolio. In our data, for instance, Government cabinet members ask an average of 3.9 questions in a single parliamentary session, ${ }^{24}$ Government backbenchers ask an average of 7.8; Opposition backbenchers ask an average of 45.6; and Opposition shadow cabinet members ask an average of 57.6. 
In our model of all questions combined, then, we include binary variables for (1) Opposition shadow cabinet member, (2) Opposition backbencher, and (3) Government backbencher. Controlling for the other factors in the model, we still expect the former to ask the most questions; we still expect those in the comparison (residual) category, Government cabinet members, to ask the fewest questions. When we consider the number of questions on specific topics, we break the first category into two variables: (1a) Opposition shadow cabinet member, with a portfolio on the relevant topic (for example, defense), and (1b) all other Opposition shadow cabinet members. We expect that all shadow cabinet members will ask more questions than backbenchers, but the Opposition defense critic, for instance, will be particularly likely to ask questions on defense.

\section{Party Proportion}

Oral questions are allocated to opposition parties roughly in proportion to their size in the House; that is, a larger opposition party will receive more questions than a smaller opposition party. Accordingly, the models include a variable for the number of seats an MP's party has in Parliament, as a proportion of all opposition seats. (This variable is equal to zero for all Government MPs.) Party proportion will not have a simple, linear effect on the number of questions asked, however. Initially, as party size (and, consequently, proportion of questions) increases, an MP's opportunity to ask questions should increase. This opportunity may increase more slowly, however, and eventually decrease, as the party reaches a certain critical size. This is a simple case of diminishing returns: as the number of people in a party increases, demand for questions will be greater, and the likelihood that any one individual asks many questions starts to decrease. This is tested with the inclusion of both the linear and quadratic forms of party proportion, with the expectation that the first coefficient will be large and positive, and the latter will be small and negative.

Party size, alongside Government/Opposition and cabinet/backbench status, should affect the number of questions asked by all MPs, regardless of topic. A second set of variables should affect the number of questions asked on particular topics. These are as follows.

\section{Parliaments and Parties}

The number of questions on a given topic will vary across both parliaments and parties, based on a topic's salience either over time or across partisans, respectively. A set of binary variables is accordingly included, accounting for the $32^{\text {nd }}, 34^{\text {th }}, 35^{\text {th }}, 36^{\text {th }}$ and $37^{\text {th }}$ parliaments. The $33^{\text {rd }}$ Parliament (the first full parliament in our dataset) is the reference cat- 
egory. Models also include a set of binary variables for the Progressive Conservatives (PC), New Democratic Party (NDP), Reform/Canadian Alliance (CA), ${ }^{25}$ and Bloc Quebecois (BQ); the Liberals are the reference category. Any systematic differences in issue salience across parties or over time will show up in these variables.

\section{Constituency Interests}

Most important for our test of dyadic representation is the effect of constituency interests. As described above, we capture these preferences in two ways. When looking at questions on defense, we capture constituency interests using a simple binary variable equal to one for all constituencies in which there is a military base. In short, we expect that a military base increases the salience of defense issues in a constituency. This has been found to be true in the US (Bartels, 1991); it seems reasonable to expect the same effect in Canada.

When looking at questions on debt/taxes and welfare, we identify constituency interests using the distribution of the vote in the last election. ${ }^{26}$ Doing so captures a more general partisan preference - essentially, a left/right ideological disposition - for each constituency using party vote shares. A similar approach has been used in some past US work (for example, Nice, 1983; Erikson and Wright, 1980). The Canadian multiparty case is slightly more complicated than the two-party case in the US, but things can be simplified somewhat using a measure in which the vote share for each party in the last election is multiplied by that party's placement on a left/right scale, as follows:

$$
\begin{aligned}
\text { Partisan Preference } & =\left(\text { Voteshare }^{\mathrm{NDP}} \times-1\right) \\
& +\left(\text { Voteshare }^{\mathrm{BQ}} \times-1\right) \\
& +\left(\text { Voteshare }^{\mathrm{Lib}} \times 0\right) \\
& +\left(\text { Voteshare }^{\mathrm{PC}} \times .5\right) \\
& +\left(\text { Voteshare }^{\mathrm{Reform}} \times 1\right) .
\end{aligned}
$$

The particular measure places the NDP and BQ one unit lower than (or left of) the Liberals, the Reform Party one unit higher (or to the right), and the PC Party midway between the Liberals and Reform. These ideological weights capture the structure of the Canadian party system from 1993 onwards; before 1993, the measure is adjusted somewhat: there is no BQ or Reform Party, and, in the absence of another party on the right, the PC vote share is weighted at -1 , one full unit right of the Liberals.

These are relatively simple weights, but they are supported by existing work on party ideological placements. The results of Benoit and Laver's elite interviews (2006) show the NDP and Reform roughly the 
same distance on either side of the Liberals, the PCs between the Liberals and Reform, and the BQ close to the NDP. ${ }^{27}$ Similarly, Budge and others' content analysis of party platforms finds the NDP and Reform roughly equidistant from the centrist Liberals (2001); those data also capture the leftward shift in the PC party once Reform emerges. ${ }^{28}$ Roughly the same ideological distribution is also evident in voters' assessments of Canadian parties. ${ }^{29}$

The resulting measure is equal to 1 if all votes go to Reform/CA (or the pre-1993 PCs); equal to -1 if all votes go to the NDP; and somewhere between as votes are distributed across the parties (as they always are).$^{30}$ In our data, the distribution is close to normal, and centred just right of centre. This is expected, given that the PCs formed the Government from 1984 to 1993 , and the combined totals for the two rightleaning parties exceeded those of the left-leaning parties in the 1993 and following elections.

This measure greatly simplifies a relatively complicated Canadian party system. Nevertheless, it likely captures the most important difference across constituencies for our purposes: the extent to which a constituency tends to be left- or right-leaning, as identified by the most recent electoral results. ${ }^{31}$ Partisan preference is thus included as our measure of constituency interests in models of debt/taxes and welfare questions. If constituency matters, even controlling for party, MPs from more leftleaning constituencies should be less likely to focus their attention on reducing both the debt and taxes, and more likely to address social welfare issues. The opposite should be true for MPs from right-leaning constituencies, ceteris paribus.

\section{Electoral Instability}

Even if constituency interests are correlated with MPs' behaviour, it remains possible that this apparently constituency-driven behaviour is not so much active representation as it is a product of electorates successfully electing MPs who are demographically or ideologically representative of the constituency. That is, it is hard to distinguish between (a) an MP who pays attention to tax breaks because she or he represents a constituency with many wealthy citizens, and (b) an MP who pays attention to tax breaks because she or he (or someone in their family) is wealthy. Practically speaking, this may not matter very much - in either case, constituency interests are being represented in Parliament. Insofar as we are interested in gauging the extent of active representation in a party-focused parliamentary system, however, the issue is of some importance.

One way to find evidence of active representation is to search for effects of electoral instability. ${ }^{32}$ If acting in a representative fashion increases an MP's chance at re-election, then we may find that those more 
concerned about losing the next election are more active in representing their constituency. Finding evidence of this would provide some evidence that behaviour in Question Period is motivated by constituency rather than MP policy preferences. More generally, it would also provide comparative evidence of the "electoral connection" (Mayhew, 1974) that makes dyadic representation worth exploring in Canada in the first place. Just as an SMP system provides a stronger incentive for dyadic representation than a fixed-list PR system, a more hotly contested constituency should motivate an MP to follow more closely the interests of her or his constituents.

This possibility is tested below in two ways. An initial test examines the degree to which the number of questions on all topics is driven by the share by which a candidate won their constituency in the last election; the relevant variable is win margin, the percentage of votes cast for the winner minus the percentage of votes cast for the second-place candidate. The expectation here is that MPs will ask more questions when they are more concerned about re-election, that is, when win margin is small. The coefficient for win margin should thus be negative. A second test uses an interaction between win margin and the relevant measure of constituency interests. This interactive effect should also be negative: constituency interests should be positively correlated with MPs' behaviour, but this connection should weaken as electoral instability increases. In short, MPs should exhibit a greater degree of representation when they feel their seat is at stake; remove political competition, and representation declines.

\section{Results}

Before moving to the multivariate model, we review some simple descriptive statistics in Table 1. The table shows the average number of questions asked by Opposition MPs (per Parliament), for each of the three issue areas. The data are broken down, first by party and then by the relevant constituency characteristics. In the first panel, for instance, we see that the average Liberal MP asks roughly 2.7 defenserelated oral questions in a given Parliament; the average PC MP asks 2.3; and so on. In short, there are no sharp party differences for this issue. When we look at the mean number of questions for MPs with or without a military base in their constituency, however, a sharp difference emerges. MPs without a military base in their constituency ask 2.7 questions; MPs with a military base ask an average of 5.0. ${ }^{33}$ Even without the multivariate setup, there is a clear connection between constituency characteristics and MP attentiveness to defense issues in oral questions. 
TABLE 1

Partisanship, Constituency Characteristics and Oral Questions

\begin{tabular}{|c|c|c|c|}
\hline & & Mean \# Questions & $(\mathrm{N})$ \\
\hline \multicolumn{4}{|l|}{ Defence } \\
\hline \multirow[t]{5}{*}{ Party } & Liberal & 2.714 & (126) \\
\hline & $\mathrm{PC}$ & 2.338 & (145) \\
\hline & NDP & 3.038 & (157) \\
\hline & Reform/CA & 3.536 & (181) \\
\hline & $\mathrm{BQ}$ & 2.829 & (140) \\
\hline \multirow[t]{2}{*}{ Military Base } & No & 2.738 & (686) \\
\hline & Yes & 5.016 & (63) \\
\hline \multicolumn{4}{|l|}{ Debt/Taxes } \\
\hline \multirow[t]{5}{*}{ Party } & Liberal & 4.143 & (126) \\
\hline & $\mathrm{PC}$ & 1.041 & (145) \\
\hline & NDP & 3.057 & (157) \\
\hline & Reform/CA & 3.127 & (181) \\
\hline & BQ & 2.021 & (140) \\
\hline \multirow[t]{2}{*}{ Unemployment } & Below median (low) & 2.827 & (404) \\
\hline & Above median (high) & 2.446 & $(36)$ \\
\hline \multirow[t]{2}{*}{ Preferences } & Below median (left) & 2.576 & $(422)$ \\
\hline & Above median (right) & 2.733 & $(345)$ \\
\hline \multicolumn{4}{|l|}{ Welfare } \\
\hline \multirow[t]{5}{*}{ Party } & Liberal & 1.563 & (126) \\
\hline & $\mathrm{PC}$ & 0.172 & (145) \\
\hline & NDP & 1.217 & (157) \\
\hline & Reform/CA & 0.033 & (181) \\
\hline & BQ & 0.721 & (140) \\
\hline \multirow[t]{2}{*}{ Unemployment } & Below median (low) & 0.579 & (404) \\
\hline & Above median (high) & 0.799 & (363) \\
\hline \multirow[t]{2}{*}{ Preferences } & Below median (left) & 0.934 & $(422)$ \\
\hline & Above median (right) & 0.377 & $(345)$ \\
\hline
\end{tabular}

Welfare questions show similar differences across the relevant proxies for constituency interests. MPs with constituencies showing leftleaning partisan preferences ask almost three times as many questions as MPs with constituencies showing right-leaning partisan preferences. ${ }^{34}$ Of course, when partisanship is not controlled for, this partisan preference measure largely captures inter-party differences; it is by definition highly related to the partisanship of the elected MP. We accordingly include one additional proxy for constituency interests: the constituency-level unemployment rate, drawn from the census closest to the year in which the MP was elected. The difference between comparative high and low unemployment constituencies is relatively small, but in the expected direction: MPs representing constituencies with unemployment rates above the median do indeed ask more welfare questions. ${ }^{35}$ That said, it is partisan- 
ship that matters most to attentiveness to welfare issues: the average NDP candidate asks 1.2 questions per Parliament, while the average Reform/CA MP asks .03. (Note that this gap supports the supposition that most welfare questions are indeed pro- as opposed to anti-welfare.) The other parties are distributed roughly as we would expect, save for the Liberals who seem to ask a relatively high number of welfare questions (indeed, more than the NDP). This distribution is a consequence of the size of the Liberal party during their time in Opposition. During this time, the Liberals occupied, on average, 61 per cent of the Opposition benches; the NDP averaged just 22 per cent. Liberals clearly had considerably more opportunity to ask questions.

Debt/taxes questions show markedly less structure across parties and demographics. The party differences that do exist reflect when parties were in Opposition as much as anything else: the Liberals were in Opposition during the debates over the Goods and Services Tax legislation; Reform/CA led the charge over the debt; and in both cases the NDP and BQ could not completely ignore the major issues of the day. The difference between MPs representing low- and high-unemployment constituencies is in the direction we might expect, but statistically insignificant. That said, the assertion that wealthier constituents will be more concerned about debt and taxes is rather tenuous, and we do not expect very much here. The difference across left- and right-leaning constituencies is similar. To the extent that there is a link between attentiveness to debt/taxes and constituency interests, we will have to rely on a multivariate setup to reveal it.

Results for the multivariate models, then, are presented in Table 2. In the first column, the total number of questions (all topics) is modelled as a function only of Government versus Opposition status, portfolio versus backbencher status, and win margin. ${ }^{36}$ The effects of portfolios and Government status are significant and in the expected direction. All MPs ask more questions than Government members with portfolios (members of cabinet); Opposition MPs with portfolios (in shadow cabinets) ask the most questions. Interpretation of the raw NBRM coefficients is rather difficult, so consider the following interpretations, based on the exponentiated coefficients: a government backbencher asks roughly 1.9 times as many questions as does a member of cabinet; an Opposition backbencher asks 4.7 times as many questions; an Opposition shadow cabinet member asks 6.4 times as many questions.

Party size also matters. The linear version of party proportion is positive, and the quadratic version negative, as expected. The coefficients suggest the following: for a backbench Opposition member, an MP whose party makes up 20 per cent of the Opposition has an expected count of 43.2; with a party making up 30 per cent of the Opposition, their expected count is 52.4; with 40 per cent of the Opposition, their expected count is 
TABLE 2

Party Size, Constituency Preferences, Electoral Instability and Oral Questions

\begin{tabular}{|c|c|c|c|c|}
\hline IV & $\begin{array}{l}\text { DV } \\
\text { All }\end{array}$ & Defense & Debt/Taxes & Welfare \\
\hline Defense Base & & $\begin{array}{l}.576^{*} \\
(.342)\end{array}$ & & \\
\hline Defense Base $*$ Win Margin & & $\begin{array}{l}-.180 \\
(1.337)\end{array}$ & & \\
\hline Partisan Preference & & & $\begin{array}{l}3.166^{* *} \\
(1.274)\end{array}$ & $\begin{array}{c}-5.062 * * * \\
(1.632)\end{array}$ \\
\hline Partisan Preference $*$ Win Margin & & & $\begin{array}{c}-4.254^{* * *} \\
(1.486)\end{array}$ & $\begin{array}{c}2.995 \\
(2.097)\end{array}$ \\
\hline Win Margin & $\begin{array}{l}-.738^{* * *} \\
(.252)\end{array}$ & $\begin{array}{c}.319 \\
(.482)\end{array}$ & $\begin{array}{c}.284 \\
(.494)\end{array}$ & $\begin{array}{r}-.804 \\
(.668)\end{array}$ \\
\hline Party Proportion & $\begin{array}{l}.055^{* * *} \\
(.008)\end{array}$ & $\begin{array}{l}.053 * \\
(.032)\end{array}$ & $\begin{array}{l}.089 * * * \\
(.034)\end{array}$ & $\begin{array}{l}.004 \\
(.047)\end{array}$ \\
\hline Party Proportion $^{2}$ & $\begin{array}{l}-.001 * * * \\
(.000)\end{array}$ & $\begin{array}{c}-.001 * \\
(.000)\end{array}$ & $\begin{array}{c}-.001 * * \\
(.000)\end{array}$ & $\begin{array}{r}-.000 \\
(.001)\end{array}$ \\
\hline Opp, no portfolio & $\begin{array}{l}1.548 * * * \\
(.236)\end{array}$ & $\begin{array}{l}2.312 * * * \\
(.635)\end{array}$ & $\begin{array}{l}1.431 * * \\
(.669)\end{array}$ & $\begin{array}{l}1.965^{* *} \\
(.781)\end{array}$ \\
\hline Opp, Other portfolio ${ }^{a}$ & $\begin{array}{l}1.863^{* * * *} \\
(.208)\end{array}$ & $\begin{array}{l}2.605 * * * \\
(.592)\end{array}$ & $\begin{array}{l}3.169 * * * \\
(.577)\end{array}$ & $\begin{array}{l}4.176^{* * * *} \\
(.898)\end{array}$ \\
\hline Opp, Topic portfolio ${ }^{\mathrm{b}}$ & & $\begin{array}{l}1.300^{*} \\
(.665)\end{array}$ & $\begin{array}{l}1.992 * * * \\
(.589)\end{array}$ & $\begin{array}{l}2.829 * * * \\
(.759)\end{array}$ \\
\hline Govt, no portfolio & $\begin{array}{l}.624 * * * \\
(.107)\end{array}$ & $\begin{array}{l}.617^{* * *} \\
(.203)\end{array}$ & $\begin{array}{l}.731 * * * \\
(.252)\end{array}$ & $\begin{array}{l}.619 * * \\
(.314)\end{array}$ \\
\hline $32^{\text {nd }}$ Parliament & & $\begin{array}{c}-1.250^{* * *} \\
(.326)\end{array}$ & $\begin{array}{c}-1.443 * * * \\
(.271)\end{array}$ & $\begin{array}{c}-2.188^{* * * *} \\
(.411)\end{array}$ \\
\hline $34^{\text {th }}$ Parliament & & $\begin{array}{c}-.773 * * * \\
(.244)\end{array}$ & $\begin{array}{r}-.123 \\
(.223)\end{array}$ & $\begin{array}{c}-1.211 * * * \\
\quad(.283)\end{array}$ \\
\hline $35^{\text {th }}$ Parliament & & $\begin{array}{c}.218 \\
(.343)\end{array}$ & $\begin{array}{c}.182 \\
(.349)\end{array}$ & $\begin{array}{c}-1.376^{* * *} \\
(.502)\end{array}$ \\
\hline $36^{\text {th }}$ Parliament & & $\begin{array}{c}.056 \\
(.364)\end{array}$ & $\begin{array}{c}-.642 * \\
(.343)\end{array}$ & $\begin{array}{c}-1.471 * * * \\
(.482)\end{array}$ \\
\hline $37^{\text {th }}$ Parliament & & $\begin{array}{c}.394 \\
(.371)\end{array}$ & $\begin{array}{c}-.915 * * \\
(.356)\end{array}$ & $\begin{array}{c}-2.041 * * * \\
(.534)\end{array}$ \\
\hline Party-PC & & $\begin{array}{c}.427 \\
(.274)\end{array}$ & $\begin{array}{l}.719^{* * * *} \\
(.261)\end{array}$ & $\begin{array}{c}-.867^{* *} \\
(.370)\end{array}$ \\
\hline Party-NDP & & $\begin{array}{r}-.013 \\
(.393)\end{array}$ & $\begin{array}{c}.585 \\
(.372)\end{array}$ & $\begin{array}{l}.006 \\
(.426)\end{array}$ \\
\hline Party-Reform & & $\begin{array}{c}-.738^{*} \\
(.443)\end{array}$ & $\begin{array}{r}-.658 \\
(.501)\end{array}$ & $\begin{array}{c}-2.476^{* * *} * \\
(.784)\end{array}$ \\
\hline Party-BQ & & $\begin{array}{c}-.865^{*} \\
(.463)\end{array}$ & $\begin{array}{r}-.625 \\
(.506)\end{array}$ & $\begin{array}{c}-1.115^{* *} \\
(.524)\end{array}$ \\
\hline Constant & $\begin{array}{l}-.232^{* *} \\
(.113)\end{array}$ & $\begin{array}{c}-3.736^{* * * *} \\
(.366)\end{array}$ & $\begin{array}{c}-4.027^{* * *} \\
(.354)\end{array}$ & $\begin{array}{c}-3.035^{* * *} \\
(.504)\end{array}$ \\
\hline $\begin{array}{l}\text { Log likelihood } \\
\mathrm{N}\end{array}$ & $\begin{array}{l}-6560.372 \\
1804\end{array}$ & $\begin{array}{c}-1979.672 \\
1804\end{array}$ & $\begin{array}{l}-1920.676 \\
1804\end{array}$ & $\begin{array}{l}-854.436 \\
1804\end{array}$ \\
\hline
\end{tabular}

Cells contain coefficients from a negative binomial regression model, with standard errors in parentheses. $* \mathrm{p}<.10, * * \mathrm{p}<.05, * * \mathrm{p}<.01$.

${ }^{a}$ Column 1: any portfolio; column 2: any portfolio other than defense; column 3: any non-economic portfolio; column 4: any portfolio not related to social welfare.

${ }^{\mathrm{b} C o l u m n}$ 2: defense portfolio; column 3: economic portfolio; column 4: social welfare portfolio. 
55.1. ${ }^{37}$ Beyond this size, the benefits for an individual MP begin to drop. With a party making up 50 per cent of the Opposition, the expected count drops to 50.2, and with 60 per cent the expected count is 39.6. An MP in a party that forms 60 per cent of the Opposition is thus likely to ask no more questions - indeed, fewer questions - than the same MP in a party that forms 20 per cent of the Opposition, ceteris paribus.

Win margin is also significant and in the expected direction. The greater the win margin, that is, the lower the electoral instability, the fewer questions a member asks. Alternatively, the tighter the race, or the greater the electoral instability, the more questions a member asks. A one-standard deviation shift in win margin (.18) leads to an average 12.3 per cent decrease in the expected number of questions. (This translates to a shift from roughly 13.9 to 12.1 oral questions by an MP in a given Parliament, ceteris paribus, and holding other variables at their means.) $)^{38}$ This first model thus provides preliminary evidence that electoral instability matters; moreover, that there is a degree of active representation in the Canadian parliament. MPs participate more when they face more competition in the next election.

Dyadic representation is addressed more directly in columns 2 through 4 of Table 2, which show models of the number of defense, debt/taxes and welfare questions, including the party and parliamentary controls, as well as the constituency interests variable interacted with win margin. In each case, the effects of Government versus Opposition and portfolio versus backbencher status are still significant and in the expected direction. Opposition portfolios increase the expected count; this is particularly true for portfolios on the specific topic in each model.

Party and Parliament variables are somewhat difficult to interpret in these models. The NDP coefficient in column 3, for instance, shows the difference between the NDP and the comparison category, Liberals, holding everything else constant. (The coefficient is .795, based on the exponentiated coefficient, an NDP MP asks roughly 2.2 times the expected number of debt/taxes questions as a Liberal MP.) But of course other things are not held constant in real life. The NDP has never had as large a seat share in Parliament, they have never formed a federal government, and at the constituency level they tend to win by smaller margins, so we cannot take party dummies themselves as good indications of the real difference between one party and another. Party differences do show up nicely in predictions, however, below.

The preference variables, combined with win margin, are the critical test of dyadic representation. And note that they have a good deal to overcome: these models test for a significant effect of these variables, even after parliaments, parties, and other institutional variables are taken into account. Indeed, we expect these variables to be significant even after we control for portfolios. In short, we expect constituency variables 
to have an effect above and beyond party and institutional variables. This is of course the crux of active, dyadic representation.

In column 2 (and as we should expect given results in Table 1), the binary military base variable is positive and significant. The (exponentiated) coefficient suggests that having a military base increases the expected count for defense questions by 83 per cent. We expect no particular direct effect of win margin here, and do not find one. The interaction between win margin and the defense base variable is negative as expected (weakening the link between constituency and parliamentary behaviour), but insignificant.

Results for debt/taxes in column 3 also suggest a link between constituency interests-measured here using the partisan preference measure - and MP behaviour. A one-standard deviation (.15) rightward (positive) shift in partisan preference leads to a 72 per cent increase in the expected count. Again, there is no direct effect of win margin, but the interaction is in this case is both negative and significant. A similar (though opposite) dynamic is apparent for questions on welfare, in the last column of Table 1. Here, a one-standard deviation (.15) leftward (negative) shift in the partisan preference measure leads to a 48 per cent increase in the expected count for welfare questions. The interaction with win margin is correctly signed, but narrowly misses statistical significance.

There is thus evidence of dyadic representation in every case in Table 1, first, in the relationship between win margin and an MP's propensity to ask questions at all, and then in the consistent relationship between measures of constituency interests and MPs' questions on three different topics. The interaction between win margin and constituency interest is in the correct direction in each of the issue-specific models, though it is statistically significant only in the case of debt/taxes questions.

The resulting combined effect of partisan preference and win margin for debt/taxes is illustrated in Figure 1; for welfare, results are illustrated in Figure 2. The figures show expected counts (of questions) over varying levels of constituency partisan preference. Rather than holding other variables constant at their means, the figures show estimates for two real-world examples: Reform/CA and NDP - two parties at opposite ends of the political spectrum and consistently in the Oppositionbackbenchers in the $36^{\text {th }}$ Parliament. ${ }^{39}$ The figures show expected counts only for the range of partisan preference in the constituencies in which Reform or NDP candidates were elected. In our data, NDP candidates were elected in constituencies with an overall partisan preferences score of between -.4 and 0 ; Reform/CA candidates were elected in constituencies with a score of between 0 and .6 .

The mediating effect of electoral instability is captured in Figures 1 and 2 by showing the effect of partisan preference at two different values 
FIGURE 1

Constituency Interests, Electoral Pressure and Questions on Debt/Taxes

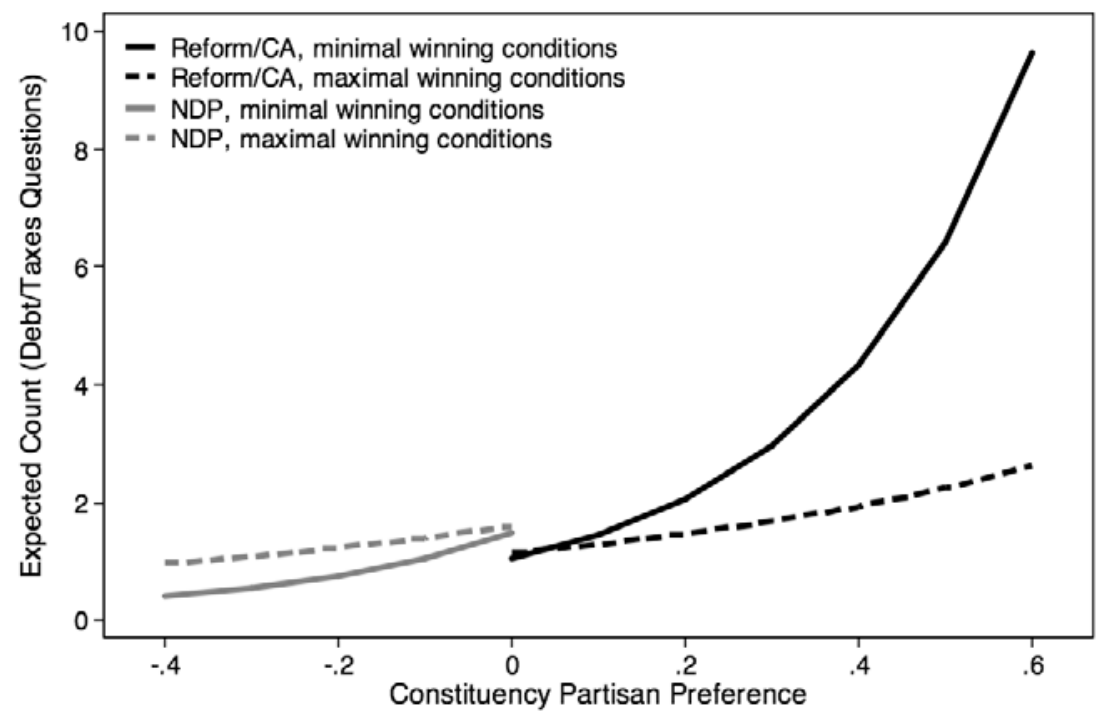

for win margin. Under "minimal winning conditions," win margin is held at .03 , a win by 3 per cent of the vote share, the $10^{\text {th }}$ percentile for win margin in our sample. Under "maximal winning conditions," win margin is held at .50 , a win by 50 per cent of the vote share, about the $90^{\text {th }}$ percentile in our sample. The figures thus capture the estimated effects of party, constituency interests and electoral instability.

In Figure 1, we see the number of debt/taxes questions increase as constituency interests move rightward. ${ }^{40} \mathrm{~A}$ combination of party, and the interests of those constituencies in which NDP candidates are actually elected, means that NDP MPs rarely ask questions on debt/taxes. Reform/CA MPs do ask such questions, and both maximally and minimally winning Reform/CA MPs ask more questions when their constituency is more clearly to the right. Under minimal winning conditions, there is an especially strong link between constituency interests and MPs' questions on debt and taxes.

Figure 2 shows a similar dynamic, though in the opposite direction. MPs from more left-leaning constituencies ask more questions on welfare; that said, no Reform MPs are elected from these constituencies, and that party's MPs accordingly rarely ask welfare questions. NDP candidates facing greater electoral instability appear more greatly affected by constituency interests. This is the expected effect, though recall that in this case the interaction is insignificant. 
FigURE 2

Constituency Interests, Electoral Pressure and Questions on Welfare

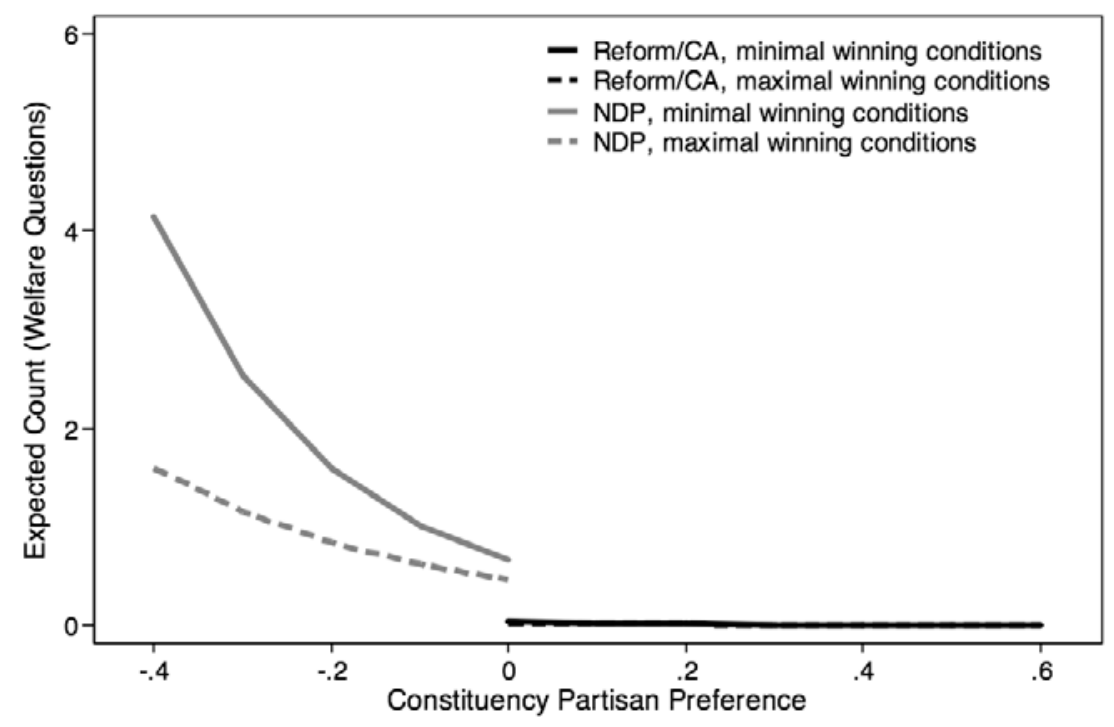

\section{Conclusions}

Miller and Stokes write that, "Substantial constituency influence over the lower house of Congress is commonly thought to be both a normative principle and a factual truth of American government" (1963: 45). The same cannot be said for most parliamentary systems, where the link between constituencies' interests and the behaviour of their respective representatives is typically muted by party discipline. The commonly accepted truth is that these systems are dominated by strong party government and leave little space for independent, constituency-responsive action by elected representatives.

There are nevertheless good reasons to believe that at least a certain degree of dyadic representation will be evident outside the US. The "normative principle" of constituency influence is built into SMP electoral systems, after all. And while it is true that in parliamentary systems legislation necessarily comes out of cabinet, there exist parliamentary venues in which individual MPs can have an effect on legislative deliberations, and possibly an effect on legislative outcomes (or other policy outcomes; see Blidook, N.d.). In a country with an SMP electoral system (such as Canada), and a parliamentary venue in which representatives have at least some freedom in their legislative behaviour (such as Question Period), limited dyadic representation seems possible, and even likely. 
These are the principal contributions of this paper, we hope: in Canada, reviving the notion that individual MPs can matter in the Canadian political process and suggesting the potential representative importance of Question Period, and, comparatively speaking, confirming the fact that there can be an element of dyadic legislative representation in a party-centred parliamentary system. It goes without saying that future work is required to more precisely identify the relationship between constituency interests and the legislative behaviour of representatives, across both countries and issues. For the time being, we are content to provide preliminary evidence that this kind of representation exists. The American Congress may be exceptional where the magnitude of dyadic representation is concerned, but the institutional incentives for dyadic representation, and that representation itself, are clearly evident elsewhere. The questions MPs ask in the Canadian Parliament are, for instance, above and beyond partisan affiliation, regularly driven by constituency characteristics.

\section{Notes}

1 Also see Weale (1999).

2 This system-level notion of representation has motivated a vast body of literature in the US, Canada, and elsewhere. See, for example, Page and Shapiro (1983); Erikson et al. (2002); Wlezien (1995, 1996, 2004); Soroka and Wlezien (2004, 2005); Petry (1999); Petry and Mendelsohn (2004). For a review of different forms of representation - system and otherwise - see, for example, Mansbridge (2003); Wlezien and Soroka (2007).

3 See, for example, Achen (1978); Bartels (1991); Erikson (1978, 1990); Erikson and Wright (1980, 1997, 2000); Fiorina (1974); Kuklinski (1977, 1978); McCrone and Kuklinski (1979); Shapiro et al. (1990); Stone (1979); Wright (1989a; 1989b); Wright and Berkman (1986). For an opposing perspective see Bernstein (1989).

4 Indeed, in recent years Canadian governments have gone so far as to use confidence measures to ensure favorable vote outcomes in the House, raising rather serious problems for the process of responsible government.

5 Using the Canadian Election Study, Blais et al. (2003) suggest that as much as 5 per cent of the vote in the 2000 Canadian federal election (outside Quebec) was determined by voter preferences for individual candidates rather than parties.

6 On the UK, see also Mitchell (1994) and Rush (2001).

7 Indeed, research on constituency service, following in large part from Fenno's influential work (1978), has much to tell us about the extent to which MPs, across various electoral systems, may focus on constituency interests and priorities. See, for example, Anagnoson (1983); Gaines (1998); Ingall and Crisp (2001); Norris (1997); Studlar and McAllister (1996).

8 The same is true of most political systems, of course, including the US. See, for example, Highton and Rocca's work (2005) on position taking by Members of Congress.

9 For a discussion of the development and process of Question Period in the Canadian House of Commons, see also Penner et al. (2006).

10 For instance, the Reform Party's oral questions, which asked for clarification on future scenarios involving unclear referendum questions and secession terms (alongside a 
Reform private members bill on these issues, the Quebec Contingency Act), is often credited as having inspired the Clarity Act (1999). See, for example, Hébert (2002). There are also multiple cases where ministers have resigned or been shuffled in which QP activity appears to have been a factor in the outcome, including, most recently, Rona Ambrose and Gordon O'Connor.

11 This figure is based on a search of the Globe and Mail in the Factiva full-text database. Note that we use the Globe and Mail as just one example here, though we expect content to be similar in many other Canadian dailies. (A parallel search of both the Toronto Star and the Calgary Herald suggests that this is the case.) The search itself is: (《("question period" or "oral questions" or "questions in the House") not "CTV's Question Period" $\rangle\rangle$, where the latter term ensures that we exclude events from the CTV program of the same name, and where the search is constrained to stories identified by Factiva as being about Canada.

12 These figures are based on the 173 Opposition MPs currently in Parliament, and exclude the party leaders and Speaker. Note that there is a good deal of variance across parties. Currently, 90 per cent of NDP candidates have websites and 96 per cent of those list oral questions; 83 per cent of Liberal MPs have websites with 59 per cent listing questions; 30 per cent of BQ candidates have websites with 85 per cent listing questions. This is just a simple descriptive test of the role of Question Period in constituency communication, of course, and cannot speak directly to the role of questions in constituency communication in the mid-1980s. That said, it does offer at least one recent picture of the role oral questions play in MPs' communication strategies. Websites were checked in the third week of July 2008, based on links from the parliamentary list of MPs at http://webinfo.parl.gc.ca/.

13 Unlike many systems, for instance, neither the question nor its topic need be submitted to the minister in advance (Marleau and Montpetit, 2000: ch. 11).

14 Based in part on personal interviews with current and past members of Parliament, as listed in the acknowledgements. For a similar story from UK MPs, see Norton (1994).

15 For the Canadian project, several codes were adjusted to reflect Canadian rather than US policies (for example, Canada Pension Plan), and several others were added to accommodate uniquely Canadian political issues (for example, National Unity). A list of Canadian topic codes is available from the authors. The dataset was coded manually, directly from Hansard, using six different coders over a two-year period. Coders went through a three-month training process before they started storing data; a random selection of questions was coded by all coders on a monthly basis. Intercoder reliability for topics was very high - after training, all coders agreed on a single major topic 95 per cent of the time, and a single minor topic 85 per cent of the time. For further details on methodology, see Penner et al. (2006) as well as the data codebook available online via the PolicyAgendas Project website (www.policyagendas. org).

16 In the Policy Agendas codebook, these categories correspond to the following codes: defense, topic 16; debt/deficit, subtopic 105; taxation, subtopic 107; social welfare, subtopics $1301-1305$.

17 First, taxes were prominent in the Mulroney Conservative Governments (both tax reduction and the new Goods and Services Tax), and then tax and debt reduction became the central issues for Reform/CA. Note also that combining federal debt/ deficit and taxes has the statistical advantage of increasing the range and variance in this dependent variable (and, in particular, reducing the number of zeros).

18 When MPs are in multiple parliaments, they appear several times in our dataset. This raises a problem for regression estimations, of course, since the cases are not completely independent of each other. This is accounted for in part by using robust standard errors, where the total number of MPs, rather than the sample size, is used in 
the estimation of standard errors. Note that another simple approach to dealing with interdependencies is simply to keep just one instance of each MP. Doing so has no substantive effect on results, so we proceed with the full model (and robust standard errors) here.

19 These data exhibit a good degree of "overdispersion," - where the standard error is greater than the mean-so the NBRM is more appropriate than the more common Poisson count data estimation. We also ran models using a zero-inflated negative binomial (ZINB) estimation. Since results did not change substantively, we rely on the simpler procedure here.

20 There are several texts offering very clear discussions of NBRMs. See, for example, Cameron and Trivedi (1998); Hilbe (2007); Long and Freese (2003).

21 Note that in most cases the subscript $i$ for $t$ does not really matter- $t$ is constant for most MPs in a given Parliament $p$. We subscript for $i$ here only for the rare cases in which an MP enters late or leaves early.

22 This error terms is distributed as a gamma distribution with mean 1 and variance $\alpha$, parameterized as $\ln \alpha$.

23 Note that $t$ appears on both sides of the equation but does not cancel out. It is not static, after all, but varies across individuals even within parliaments. Indeed, this is why we subscript for both $i$ and $p$ for $t$ - the subscript $i$ would be redundant (that is, $t$ would vary only across $p$ ) were it not for the rare cases in which an MP enters late or leaves early.

24 Note that none of these questions will be asked by members with major portfolios. Those senior members of the cabinet will not ask any oral questions.

25 Note that the Reform Party existed only for the 1993 and 1997 elections. In 2000, Reform changed its name to the Canadian Alliance and then merged in 2003 with much of the Progressive Conservative Party to become the Conservative Party of Canada.

26 An alternative is to use a census measure of, for example, median household income as a surrogate for constituency preferences in these models. Income data are not readily available at the federal electoral district level before the 1991 Census, however, leaving missing data for well over half our sample.

27 More precisely, on a 20-point left-right scale, Benoit and Laver place the parties as follows: NDP 4.93; BQ 7.2; Liberal 11.08; PC 13.6; Reform 17.46.

28 The average left-right score for parties in the 1984-1997 elections is NDP -31.9; BQ (unavailable); Liberal -6.4; PC 16.45; Reform (1997 only) 40.5. These data put Reform a little further to the right, then, but this is relatively early in the party's existence. Over time, the PC's left-right score is as follows: in 1988, 18.3; in 1993, 24.6; in 1997 (with the electoral rise of the Reform Party), 10.6.

292000 Canadian Election Study (Blais et al., 2004) respondents were asked, "Some people talk about parties being on the left or on the right. Do you think the [party name] is on the left, on the right, or in the centre?" The "net" score for each party $\%$ saying right minus \% saying left - was: NDP - 24.7; BQ 11.3; Liberal 9.8; Conservative 20.5; Canadian Alliance (Reform) 27.4. Of course, these figures are not directly comparable with the interval-level measures in work on manifestos or elite interviews. Here, we have respondents selecting just one of three broad categories, within which there will be much unobserved variance in ideological placements. Nonetheless, results do correspond roughly with the other indicators.

30 Note that two quite different distributions can lead to same partisan preference value: everyone voting Liberal, or 50 per cent voting left and the other 50 per cent voting right, lead to the same result, for instance. The measure nevertheless captures the median voter in each case.

31 We did experiment with other versions of partisan preference, scoring, for instance, the $\mathrm{BQ}$ as 1.5 rather than 1 , and so on. The changes in specification have only a 
minor impact on the results, so we use what we believe to be the closest approximation of existing party placement measures here.

32 Another is to control for an MP's own demographic traits and experience. MPs' previous occupations are available from the Library of Parliament, for instance. These are not clearly related to attentiveness to particular issues, however. We chose not to deal with this directly here, though this is certainly an avenue for future analysis.

33 The different is significant at $\mathrm{p}<.01$, based on a one-tailed t-test.

34 The different is significant at $\mathrm{p}<.01$, based on a one-tailed t-test.

35 The different is statistically significant at $\mathrm{p}=.08$, based on a one-tailed t-test.

36 Results in Table 1 use all MPs, including Government members who ask very few questions. To ensure that results - particularly where party size is concerned-are not being driven by the inclusion of these Government MPs; we estimated the same model with only Opposition MPs. Doing so makes little difference to these institutional variables, so we show the full model here.

37 These estimates are generated using the Clarify routine in STATA. See King et al. (2000).

38 Holding other variables at their means provides a useful shortcut here, but is admittedly rather peculiar when independent variables include a series of dummy variables for which anything other than 0 or 1 is impossible. We avoid this problem in the simulations below by specifying specific and realistic values for all variables in the model.

39 Party, parliament, and party size variables are thus fixed at the appropriate levels.

40 For the sake of clarity of presentation, the figures show predicted values without margins of error. Also, because we show predictions for very particular cases (NDP and Reform $36^{\text {th }}$ Parliament backbenchers), the margins of error around the estimates are considerably larger than predictions that simply hold all other variables at their mean. The coefficients in Table 1, of course, provide indications of statistical significance across the entire sample.

\section{References}

Achen, Christopher H. 1978. "Measuring Representation." American Journal of Political Science 22: 475-510.

Anagnoson, J. Theodore. 1983. "Home Style in New Zealand." Legislative Studies Quarterly 8 (2): 157-75.

Anderson, Cameron and Elizabeth Goodyear-Grant. 2005. "Conceptions of Political Representation in Canada: An Explanation of Public Opinion." Canadian Journal of Political Science 38: 1029-58.

Atkinson, Michael. 1978. "Policy Interests of Provincial Backbenchers and the Effects of Political Ambition." Legislative Studies Quarterly 3: 629-46.

Atkinson, Michael M. and Paul G. Thomas. 1993. "Studying the Canadian Parliament". Legislative Studies Quarterly 18 (3): 423-51.

Bartels, Larry M. 1991. "Constituency Opinion and Congressional Policy Making: The Reagan Defense Build Up." American Political Science Review 85 (2): 457-74.

Baumgartner, Frank and Bryan Jones. 2003. Policy Dynamics. Chicago: University of Chicago Press.

Benoit, Kenneth and Michael Laver. 2006. Party Policy in Modern Democracies. Routledge Research in Comparative Politics 19. London: Routledge.

Bernstein, Robert A. 1989. Elections, Representation, and Congressional Voting Behaviour: The Myth of Constituency Control. Englewood Cliffs, NJ: Prentice Hall.

Blais, André, Elisabeth Gidengil, Agnieszka Dobrzynska, Neil Nevitte and Richard Nadeau. 2003. "Does the Local Candidate Matter? Candidate Effects in the Canadian Election of 2000." Canadian Journal of Political Science 36 (3): 657-64. 
Blais, Andre, Elisabeth Gidengil, Richard Nadeau and Neil Nevitte. 2004. Canadian Election Survey, 2000 [Computer file]. Available through the Canadian Opinion Research Archive, http://www.queens.ca/cora.

Blidook, Kelly. N.d. "Exploring the role of 'legislators' in Canada: Do Members of Parliament influence policy?" Journal of Legislative Studies, forthcoming 2010.

Budge, Ian, Hans-Dieter Klingemann, Andrea Volkens, Judith Bara, Eric Tannenbaum, Richard Fording, Derek Hearl, Hee Min Kim, Michael McDonald and Silvia Mendes. 2001. Mapping Policy Preferences: Parties, Electors and Governments: 1945-1998. Oxford: Oxford University Press.

Cain, Bruce, John Ferejohn and Morris Fiorina. 1987. The Personal Vote: Constituency Service and Electoral Independence. Cambridge MA: Harvard University Press.

Cameron, A.C. and P.K. Trivedi. 1998. Regression Analysis of Count Data. Cambridge: Cambridge University Press.

Carey, John M. and Matthew Soberg Shugart. 1995. "Incentives to Cultivate a Personal Vote: A Rank Ordering of Electoral Formulas." Electoral Studies 14 (4): 417-39.

Carty, R. Kenneth, Lisa Young and William P. Cross. 2000. Rebuilding Canadian Party Politics. Vancouver: UBC Press.

Chester, Daniel N. and Nona Bowring. 1962. Questions in Parliament. Oxford: Clarendon Press.

Clarke, Harold D. and Allan Kornberg. 1992. "Do National Elections Affect Perceptions of MP Responsiveness? A Note on the Canadian Case." Legislative Studies Quarterly 17: $182-204$.

Clausen, Aage R. 1973. How Congressmen Decide: A Policy Focus. New York: St. Martin's.

Crimmins, James E. and Paul Nesbitt-Larking. 1996. "Canadian Prime Ministers in the House of Commons.” Journal of Legislative Studies 2 (3): 145-71.

Dahl, Robert A. 1971. Polyarchy. New Haven: Yale University Press.

Diermeier, Daniel and Timothy Feddersen. 1998. "Cohesion in Legislatures and the Vote of Confidence Procedure." American Political Science Review 92: 611-621.

Docherty, David Campbell. 1997. Mr. Smith Goes to Ottawa : Life in the House of Commons. Vancouver: UBC Press.

Edelman, Murray. 1964. The Symbolic Uses of Politics. Urbana: University of Illinois Press.

Edelman, Murray. 1985. "Political Language and Political Reality." Political Science and Politics 18: 10-19.

Erikson, Robert S. 1978. "Constituency Opinion and Congressional Behavior: A Reexamination of the Miller-Stokes Representation Data." American Journal of Political Science 22: 511-535.

Erikson, Robert S. 1990. "Roll Calls, Reputations, and Representation in the U.S. Senate.” Legislative Studies Quarterly 15(4): 623-642.

Erikson, Robert S., Michael B. MacKuen and James A. Stimson. 2002. The Macro Polity. Cambridge: Cambridge University Press.

Erikson, Robert S. and Gerald C. Wright. 1980. "Policy Representation of Constituent Interests." Political Behaviour 2(1): 91-106.

Erikson, Robert S. and Gerald C. Wright. 1997. "Voters, Candidates, and Issues in Congressional Elections.” In Congress Reconsidered, ed. Lawrence C. Dodd and Bruce I. Oppenheimer. $6^{\text {th }}$ ed. Washington DC: C.Q. Press.

Erikson, Robert S. and Gerald C. Wright. 2000. "Representation of Constitution Ideology in Congress." In Continuity and Change in House Elections, ed. David W. Brady, John F. Cogan and Morris P. Fiorina. Stanford CA: Stanford University Press.

Erikson, Robert S., Gerald C. Wright and John P. McIver. 1993. Statehouse Democracy: Public Opinion and Policy in the American States. Cambridge: Cambridge University Press.

Fenno, Richard. 1978. Home Style: House Members in Their Districts. Boston: Little Brown. 
Fiorina, Morris P. 1974. Representatives, Roll Calls, and Constituencies. Lexington MA: Lexington Books.

Franklin, Mark N. and Philip Norton, ed. 1993. Parliamentary Questions. Oxford: Oxford University Press.

Franks, C.E.S. 1987. The Parliament of Canada. Toronto: University of Toronto Press.

Gaines, Brian. 1998. "The Impersonal Vote? Constituency Service and Incumbency Advantage in British Elections, 1950-1992." Legislative Studies Quarterly 23 (2): 167-95.

Hébert, Chantal. 2002. "Harper takes pragmatic approach to Quebec," Toronto Star, 26 April A25.

Heitshusen, Valeri, Garry Young and David M. Wood. 2005. "Electoral Context and MP Constituency Focus in Australia, Canada, Ireland, New Zealand and the United Kingdom." American Journal of Political Science 49 (1): 32-45.

Highton, Benjamin and Michael S. Rocca. 2005. "Beyond the Roll-Call Arena: The Determinants of Position Taking in Congress." Political Research Quarterly 58(2): 303-16.

Hilbe, J. M. 2007. Negative binomial regression. Cambridge MA: Cambridge University Press.

Hix, Simon. 2002. "Parliamentary Behavior with Two Principals: Preferences, Parties and Voting in the European Parliament." American Journal of Political Science 46 (3): 688-98.

Howlett, Michael. 1998. "Predictable and Unpredictable Policy Windows: Institutional and Exogenous Correlates of Canadian Federal Agenda-Setting." Canadian Journal of Political Science 31 (3): 495-524.

Huber, John D. 1996. "The Vote of Confidence in Parliamentary Democracies." American Political Science Review 90 (2): 269-82.

Hurley, Patricia A. 1982. “Collective Representation Reappraised." Legislative Studies Quarterly 7 (1): 119-36.

Ingall, Rachel and Brian Crisp. 2001. "Determinants of Home Style: The Many Incentives for Going Home in Columbia." Legislative Studies Quarterly 26 (3): 487-512.

Kam, Christopher. 2001. "Do Ideological Preferences Explain Parliamentary Behaviour: Evidence from Great Britain and Canada." Journal of Legislative Studies 7 (4): 89-126.

King, Gary, Michael Tomz and Jason Wittenberg. 2000. "Making the Most of Statistical Analyses: Improving Interpretation and Presentation." American Journal of Political Science 44 (2): 341-55.

Kingdon, John W. 1973. Congressmen's Voting Decisions. New York: Harper and Row.

Kornberg, Allan. 1966. "Caucus and Cohesion in Canadian Parliamentary Parties." American Political Science Review 60: 83-92.

Kornberg, Allan. 1967. Canadian Legislative Behavior. New York: Holt, Rinehart and Winston.

Kornberg, Allan and William Mishler. 1976. Influence in Parliament. Durham NC: Duke University Press.

Kuklinski, James H. 1977. "District Competitiveness and Legislative Roll Call Behavior: A Reassessment of the Marginality Hypothesis." American Journal of Political Science 20: 627-38.

Kuklinski, James H. 1978. "Representation and Elections: A Policy Analysis." American Political Science Review 72: 165-77.

Long, J. Scott and Jeremy Freese. 2003. Regression Models for Categorical Dependent Variables Using Stata. College Station TX: Stata Press.

Mallory, J. R. 1971. The Structure of Canadian Government. Toronto: Macmillan.

Mansbridge, Jane. 2003. "Rethinking Representation." American Political Science Review 97 (4): 515-52.

Marleau, Robert and Camille Montpetit. 2000. House of Commons Procedure and Practice. Ottawa: House of Commons. 
Mayhew, David R. 1974. Congress: the Electoral Connection. New Haven: Yale University Press.

Mayhew, David R. 2001. “Observations on 'Congress: The Electoral Connection' a Quarter Century after Writing It.” PS: Political Science and Politics 34 (2): 251-52.

McCrone, Donald J. and James H. Kuklinski. 1979. "The Delegate Theory of Representation." American Journal of Political Science 23: 278-300.

Miller, Warren E. and Donald E. Stokes. 1963. "Constituency Influence in Congress." American Political Science Review 57: 45-56.

Mitchell, Austin. 1994. "Backbench Influence: A Personal View." Parliamentary Affairs 47 (4): 687-704.

Mughan, Anthony and Roger Scully. 1997. "Accounting for Change in Free Vote Outcomes in the House of Commons." British Journal of Political Science 27 (4): 619-59.

Nice, David C. 1983. "Representation in the States: Policymaking and Ideology." Social Science Quarterly 64: 404-11.

Norris, Pippa. 1997. “The Puzzle of Constituency Service.” Journal of Legislative Studies 3 (2): 29-49.

Norton, Philip. 1994. "The Growth of the Constituency Role of the MP." Parliamentary Affairs 47 (4): 705-21.

Page, Benjamin I. and Robert Y. Shapiro. 1983. "Effects of Public Opinion on Policy." American Political Science Review 77: 175-90.

Penner, Erin, Kelly Blidook and Stuart Soroka. 2006. "Legislative Priorities and Public Opinion: Representation of Partisan Agendas in the Canadian House of Commons." Journal of European Public Policy 16: 1006-20.

Petry, Francois. 1999. "The Opinion-Policy Relationship in Canada." Journal of Politics 61: $540-50$.

Petry, Francois and Matthew Mendelsohn. 2004. "Public Opinion and Policy Making in Canada, 1995-2001.” Canadian Journal of Political Science 37 (3): 505-529.

Pitkin, Hanna Fenichel. 1967. The Concept of Representation. Berkeley CA: University of California Press.

Pool, Ithiel de Sola, Robert P. Abelson and Samuel L. Popkin. 1965. Candidates, Issues, and Strategies: A Computer Simulation of the 1960 and 1964 Presidential Elections. Cambridge MA: MIT Press.

Rush, Michael. 2001. The Role of the Member of Parliament Since 1868: From Gentlemen to Players. New York: Oxford University Press.

Savoie, Donald J. 1999. Governing from the Centre: The Concentration of Power in Canadian Politics. Toronto: University of Toronto Press.

Shapiro, Catherine R., David W. Brady, Richard A. Brody and John A. Ferejohn. 1990. "Linking Constituency Opinion and Senate Voting Scores: A Hybrid Explanation." Legislative Studies Quarterly 15 (4): 599-621.

Soroka, Stuart N. 2002a. Agenda-Setting Dynamics in Canada. Vancouver: UBC Press.

Soroka, Stuart N. 2002b. "Issue Attributes and Agenda-Setting by Media, the Public and Policymakers in Canada." International Journal of a Public Opinion Research 14 (3): 264-85.

Soroka, Stuart N. and Christopher Wlezien. 2004. "Opinion Representation and Policy Feedback: Canada in Comparative Perspective." Canadian Journal of Political Science 37 (3): 531-60.

Soroka, Stuart N. and Christopher Wlezien. 2005. "Opinion-Policy Dynamics: Public Preferences and Public Expenditure in the United Kingdom." British Journal of Political Science 35 (4): 665-689.

Stewart, John B. 1977. The Canadian House of Commons: Procedure and Reform. Montreal: McGill-Queen's University Press.

Stone, Walter J. 1979. "Measuring Constituency-Representative Linkages: Problems and Prospects." Legislative Studies Quarterly 4 (4): 623-39. 
Strom, Kaare. 1997. "Rules, Reasons, and Routines: Legislative Roles in Parliamentary Democracies.” Journal of Legislative Studies 3 (1): 155-74.

Studlar, Donley and Ian McAllister. 1996. "Constituency Activity and Representational Roles among Australian Legislators." Journal of Politics 58 (1): 69-90.

Weale, Albert. 1999. Democracy. New York: St. Martin's.

Weber, Ronald E., Anne H. Hopkins, Michael L. Mezey and Frank Munger. 1972. "Computer Simulation of State Electorates." Public Opinion Quarterly 36: 49-65.

Weber, Ronald E. and William R. Shaffer. 1972. "Public Opinion and American State Policy Making." Midwest Journal of Political Science 16: 633-99.

Weissberg, Robert. 1978. "Collective vs. Dyadic Representation in Congress." American Political Science Review 72: 535-47.

Wilson, Frank L. and Richard Wiste. 1976. "Party Cohesion in the French National Assembly: 1958-1973.” Legislative Studies Quarterly 1: 467-90.

Wlezien, Christopher. 1995. "The Public as Thermostat: Dynamics of Preferences for Spending." American Journal of Political Science 39: 981-1000.

Wlezien, Christopher. 1996. "Dynamics of Representation: The Case of U.S. Spending on Defence.” British Journal of Political Science 26: 81-103.

Wlezien, Christopher. 2004. "Patterns of Representation: Dynamics of Public Preferences and Policy," Journal of Politics 66: 1-24.

Wlezien, Christopher and Stuart Soroka. 2007. "The Relationship between Public Opinion and Policy." In The Oxford Handbook of Political Behavior, ed. Russel J. Dalton and Hans-Dieter Lingemann. Oxford: Oxford University Press.

Wood, David M. and Jack T. Pitzer. 1982. "Comparing Parliamentary Voting on European Issues in France and Britain." Legislative Studies Quarterly 7: 101-17.

Wright, Gerald C. 1989a. "Policy Voting in the US Senate: Who is Represented?" Legislative Studies Quarterly 14: 465-86.

Wright, Gerald C. 1989b. "Level-of-Analysis Effects on Explanations of Voting: The Case of US Senate Elections." British Journal of Political Science 18: 381-98.

Wright, Gerald C. and Michael B. Berkman. 1986. "Candidates and Policy in US Senatorial Elections.” American Political Science Review 80: 576-90. 